\title{
オ7セット·キリヤー方式 TV Offset-Carrier System
}

\section{1. 緒言}

わが国のテレビジョン放送も既に東京汇 3 局, 大阪お よび名古屋にそれぞれ 1 局が開局され，更に全国に亘っ て着々置局計画が進められているが, 現在これに使用し 得る VHF チャンネルは僅が第 3 (102〜108 Mc), 第 $4(170 \sim 176 \mathrm{Mc})$ ，第 5 (176 182 Mc) 抢よび第 6 (182 $188 \mathrm{Mc}$ ) チャンネルの 4 波に限られているため(他に第 1 および第 2 チャンネルの 2 波が予定されているが現在 まだ使用が認められていない), 比較的近距離の放送局 でも同一チャンネルを使用する場合が予想される。

テレビジョンに括ける同一周波混信は一般の無線局の 場合と同様, 希望波と妨害波の僅少な差周波数によるビ 一トに基づく妨害が最もいちじるしく, 受像画面に白黒 の縞模様として現われる。この斿害縞の数はビート周波 数に比例して增减し，完全同一周波となれば消減し，ビ 一ト周波数がある程度高くなると縞数は増加して非常に 細かくなり，共に受像画面はいちじるしく改善される。 この現象を利用した混信軽减法が同期方式(1)およびオフ セット・キャリヤー方式で, 特汇後者は容易に実施され, かつ効果的であることが CCIR でも確認され( ()), 米国に おいてはチャンネルプラン棌用されている。わが国に 打いて子既汇室内実験 ${ }^{(3)}$ 並びに実地試験汇よりその有効 なことが認められ, 現在東京 JOAK-TV と名古屋 JOCK -TV の両局間に実施されて相当な効果を挙代ている。

\section{II. オフセット・キャリャー方式による 混信改善機構}

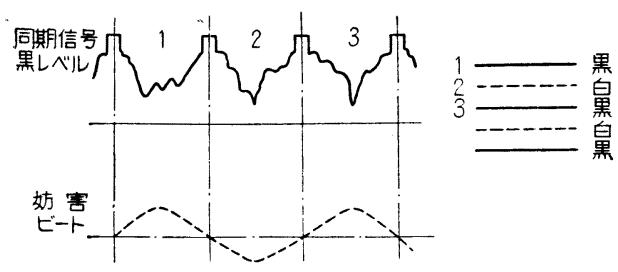

第1図オフセット・キャリヤー方式の原 理的説明図

\author{
$\mathrm{NHK}$ 施設局計面部沢村吉克 \\ " " 演奏設備部 林 和夫
}

TV 受像機が同一周波好害を受けている場合に，希望 波と混信波の差周波数の変化に対応して，画面に現われ る妨害縞模様はきわめて複雑ではあるが規則正しい変化 を示すので，まずこれについて調べることにする。

いま受像画面に希望波と混信波の差周波数に相当する ビートが重合すると, 第 1 図のごとくビートの半周期毎 の極性変化に応じて, 走査線は黒ずんだり, あるいは反 対に白っぽくなる。従って，ビート周波数が低く，ビ一 トの極性変化が比較的緩慢であれば, 走査線は連続的に 纆まって黒または白となり，画面上には太い縞模様が現 われるが, ビート周波数が高くなり, 極性変化の周期が 短くなるにつれて数 10 本から 10 数本, 数本と云った具 合に連続して黒または白になる走査線の本数は徐々に減 少してくるので, 画面上の横縞は次第に細くなり, 本数 は増してくることになる。このようにしてビート周波数 がちょ とど線周波数の $1 / 2$ になる，1フィールドでは 走査線は 1 本ごとに交互に黒と白になり，これを越えて ビート周波数が更に高くなると, 走查線は部分的に黒ま たは白となる。このためビート周波数がちょ 数と一致すると, 各走査線は半分ずつ黒または白とな り, 視覚的には画面全体が縦こ黒または白で二分された ようになる。

更にこれを 2 フレームを通じて見ると，第 1 のフレー ムの縞模様と，これに続く第 2 のフレムの縞模様とで 画面上黒または白縞の出る位置がそれぞれ一致している 場合と, 全く逆転する場合，あるいは一部ずつ打消され る場合とがある。従って視覚的には 4 フィールドが 1 組 となって混信改善機構が成立っていることがわかる。

上述のよ 5 にフレーム, 寸なわち 4 フィールドが 1 単位となる関係上，この繰返し周波数 $15 \mathrm{c} / \mathrm{s}$ と搬送波同 志のビート周波数との関係は密接である。

いま $n$ を正の整数とし，ビート周波数 $F$ を $F=n \times 15(\mathrm{c} / \mathrm{s})$

で現わし， $n=1,2,3, \cdots \cdots$ の場合につき，ビート周波 数と画面に現われる縞模様との関係を示すと第 2 図のよ うになる。 
(1) 式で $n$ が整数以外の值のときには, 縞模様は上ま たは下方に流れることになるが， $n$ が整数であってもビ 一トの位相が変ればやはり縞模様は流れるよ5に見える。 いまビート周波数と施害縞の関係を線周波数の $1 / 2 を$ 境として大別して考えると，次のよ5になる。

（1）ビート周波数が線周波数の $1 / 2$ 以下の場合：

この場合には走査線の各本の全体が黒または白となり， これらが 2 本以上緾まって画面に現われるために, 画面 には必ず水平な横縞模様が現われる。一般的表現をする と，(1) 式で $n$ を整数とし，第 1 表が得られる。ここで 画面が黒と白の横縞模様となるのは, $n=$ 偶数で, $n / 2=$ 偶数の場合に限られることがわかる。従って黒縞の本数 は $60 \mathrm{c} / \mathrm{s}$ の整数倍となる。

（2）ビート周波数が線周波数の $1 / 2$ に等しい場合：

この場合には, 走査線の各本は順次に黒と白に交互に 現われるから，飛越走査により第 1 フレームでは 2 本ず つ隣接して交互に黒と白になり， $n=525$ があるから， $n$ =奇数で $\frac{n+1}{2}=$ 奇数の場合の一般原則により, 第 2 フ レームでは黒と白になる位置が逆転し，4フィールドを 通じて見ると, 相互に打消し合って視覚的には何ら妨害 の無い場合の画面と差異のない良質の画面が得られるこ とになる。

（3）ビート周波数が線周波数の $1 / 2$ 以上の場合：

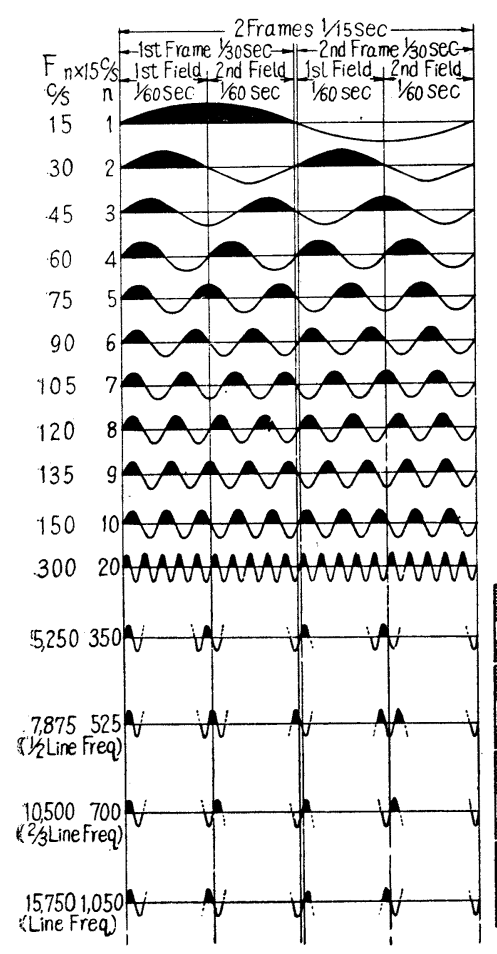

縞の状態 1st Frame 2nd Frame ist Frame 2nd Frame
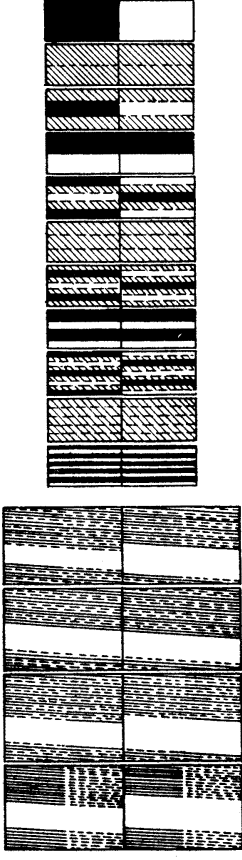

第 2 図オフセット方式の混信改善機構の説明

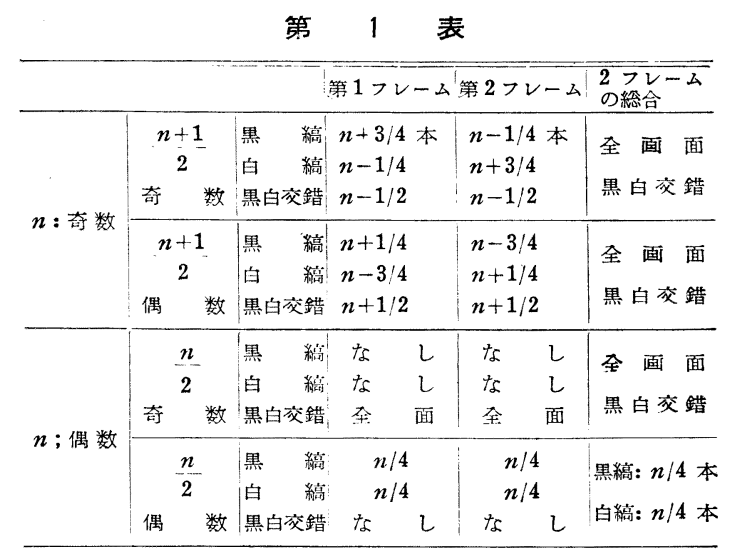

第 2 表

\begin{tabular}{|c|c|c|c|c|}
\hline$n$ & $n / 2$ & $n$ の籍 囲 & 周波数範囲 $\mathrm{kc}$ & 面面の縞模様 \\
\hline 偶 & 奇 & $\begin{array}{c}525<n<1,050 \\
n=1,050\end{array}$ & $\begin{array}{c}7.875 \sim 15.750 \\
15.750\end{array}$ & \begin{tabular}{|c|c|} 
右 下 \\
縰に黑と白で2等分
\end{tabular} \\
\hline 数 & 数 & $1,050<n<1,575$ & $15.750 \sim 23.625$ & 右 \\
\hline
\end{tabular}

この場合には 1 本の走査線は部分的に黒と白に分割さ れる。この分布方式もまた (1) 式および第 1 表の一般原

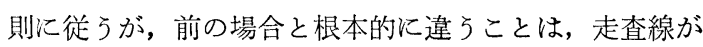
部分的に黒または白となる関係上，画面の縞模様も水平 ではなく,画面全体がきれぎれの棒模様となるか, あるい は斜め上方または下方に向 5 比軗的太い縞が現われるこ とである。一般的に云って, 黒縞の現われる周波数と模 様との関係を(1) 式に基ついて更に詳しく調べると第 2 表のよ5になる。これからわかるよ $5 に, n=$ 偶数で $n / 2$ 二奇数の場合には, ビート周波数が線周波数の $1 / 2$ より 大きくなるに従い，黒または白縞は徐々に右回転をして 斜めになり，ちょ5ど線周波数に等しくなると縱に黒と 白とで画面が 2 等分され, 更にビート周波数が線周波数 を越えても縞は右回転を続け，縞は斜め右上りとなり， 線周波数の $3 / 2$ で再び水平となり, 以後はこの繰作を繰返 す。ビート周波数が第 2 表以外の值のときには, 画面の 模様は極めて複雑でモザイク模様を呈することになる。

\section{III. 室内視覚試験}

オフセット・キャリヤー方式は上述のごとく希望波と 妨害波の映像搬送波を僅かにずらせることにより, 視覚 的に妨害を軽減しょうとする方式であるので, この方式 を適用した際の画面の良し悪しの判定は, 見る人の個人 的視覚差, 視距離, 受像機の置かれた場所の光学的諸条 件等により左右されるであろうから，妨害改善度を数量 的に求めるには, 多数の人々による視覚試験結果から得 られる統計的判定にまたなければならないことになる。 そこで基礎的な試験として，まず室内における視覚試験 


\begin{tabular}{|c|c|c|c|}
\hline 項 & 条 & 件 & 備 \\
\hline 適視距離 & $\begin{array}{l}8 \mathrm{H} \sim 10 \mathrm{H}: \mathrm{RCA} \\
7 \mathrm{H}-9.5 \mathrm{H}: \mathrm{RCA}\end{array}$ & $\begin{array}{l}\text { del } 9 \mathrm{~T}-105 \\
\text { del } 4 \mathrm{~T}-101\end{array}$ & $\begin{array}{l}\text { H は圂面の } \\
\text { 綎陌 }\end{array}$ \\
\hline $\begin{array}{l}\text { 評 価分類 } \\
\text { 面面の摄度 }\end{array}$ & $\begin{array}{l}7 \quad \text { 段 } \\
9 \mathrm{ft} \text {-iumbert }\end{array}$ & & 第 4 表参照 \\
\hline 試験参加者 & “尃門”’ょよび“一股” & グループ:备7名 & \\
\hline 試跧画面 & $\begin{array}{l}\text { スタジオ放送: JOAK- } \\
\text { フイルムム敃: JOAK- } \\
\text { テストパターシ或は幻灯 }\end{array}$ & 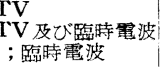 & \\
\hline
\end{tabular}

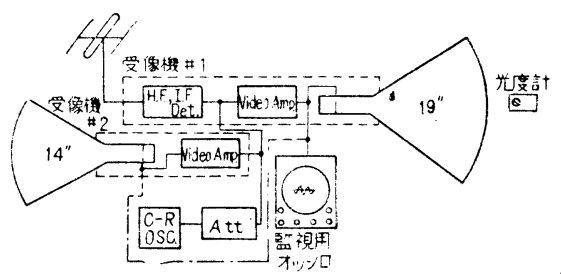

第3図試 験 装 置

を行ったのでこれについての概略を説明する。

試験に際しての諸条件は, 受像機としてRCA の 14 in および 19 in のものを用い，画面評価を行了場合の画面 の輝度および適視距離等は試験参加者 1 人 1 人について 調査し, 最適なるものとしてこれらを第 3 表た示すよう に決定した。

試験装置としては第 3 図に示すような方法を採用した。 この場合，希望波として JOAK-TV の電波を利用し， これを受像機で受像し、別等価妨害信号として映像增 幅器の入力端に C-R 発振器から 2 局の搬送周波数の差 に相当する周波数を適当な振巾で印加することとした。

これによると混信電波が受像機高周波端に同時に存在す～ る場合と全く等しい妨害効果を画面に与兄ることになる。

画面を評価するに際しては，混信波のない受像画面を 基準とし, 妨害の程度に応じて画面評価の段階を分類し, 第 4 表に示すとおり，七つの評価段階を設けた。

なお試験参加者は“尃門”グループとして，テレビ技 術に関する知識または経験を有する人々と, “一般”グ ループとして，技術的には素人であるがテレビには興味 をもち、これまでにもしばしば聴視の経験ある人々とに 分預し，各 7 名ずつ 2 組に大別した。

上述の諸条件の下にテスト・パターン,幻灯掞よびスタ ジオ放送等につき約 10 日間に亘 り延 266 人について試験を行った 結果は第4図に示すようになった。

この結果は, それぞれ“専門” および“一般”グループによって 得られた結果を総合平均したもの である。これより判るよ5に, 希望 波と混信波の差周波数が線周波数 の $1 / 2$ の奇数倍 $(7.875 \mathrm{kc}, 23.625 \mathrm{kc}$
等）となったときには, 画面の状態はいちじるしく改善 され, 線周波数の整数倍 ( $15.75 \mathrm{kc}, 31.5 \mathrm{kc}$ 等) の場 合には，改善度は全く無くなることがわかる。また放送 番組の種類に対する改善度はまことに区々で, 明膫な相 関関係は認め得なかった。

これらの試験結果から, 全種目の平均についての改善 度を求めると, 第 5 表のと打りとなり, 諸外国に拈ける 試験結果とかなりよく一致している。

\section{IV. 実 地 試 験}

昭和 29 年 8 月名古屋局 (JOCK-TV) の $10 \mathrm{~kW}$ 增力 に伴い，同局が東京局 (JOAK-TV) と同一周波数（第 3 チャンネル)であるため, 両局の電界強度比が $20 \sim 30 \mathrm{db}$ 以下の静岡県, 長野県, 新潟県等の一部に混信妨害を生 じ，その対策として前記室内実験汇おいて有効性が認め られたオフセット・キャリヤー方式を実施するため, 同 年 9 月下旬静岡県民会館屋上に於て実地試験を行った。

試験場所における東京局および名古屋局の電界強度

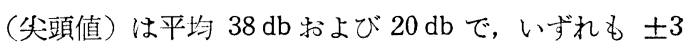
$\mathrm{db}$ 程度の緩慢なフェージングを伴っており, 両局の電 界比は $18 \pm 6 \mathrm{db}$ であった。また東京向 5 素子八木アン テナを屋上約 $6 \mathrm{~m}$ の高さ（地上高約 $31 \mathrm{~m}$ ) に設備した とき, アンテナの指向性により約 $13 \mathrm{db}$ S/I 比が改善さ れ，受像機入力端に打ける $\mathrm{S} / \mathrm{I}$ 比は $31 \pm 6 \mathrm{db}$ となった。 この場合の受像画面は第 5 図 (a)のごとく, 多少のス) 一状雑音を伴い, 更に同一周波混信による水平の妨害縞 があるいは早くあるいは幄く，またあるときは上方にあ

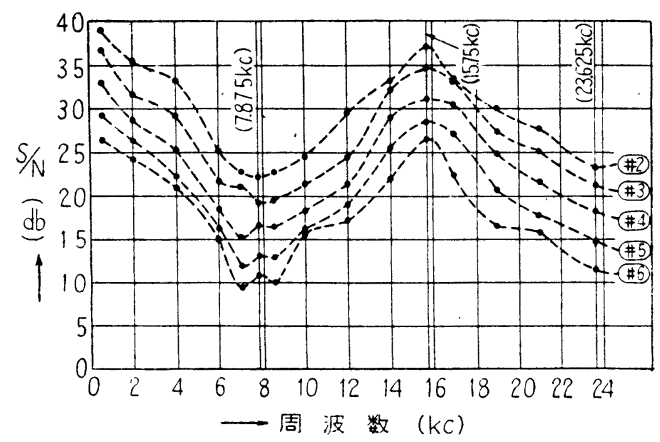

第 4 図試験結果（全種目平均）

第 4 表

\begin{tabular}{|c|c|c|c|}
\hline $\begin{array}{l}\text { 評価の } \\
\text { 番 号 }\end{array}$ & 項 & 容 & 備 \\
\hline 1 & 極めて良好な婳面 & 妨害の全く認められない面面 & Not Perceptible \\
\hline 2 & 良好な面面 & かすかながら妨害の認められる面面 & Just Perceptible \\
\hline 3 & 実用的面面 (I) & $\begin{array}{l}\text { 妨害のあることは明膫であるが, 映像 } \\
\text { の賔はほとんと損われない画面 }\end{array}$ & $\begin{array}{l}\text { Definitely perceptible, but only } \\
\text { slight impairment to picture }\end{array}$ \\
\hline 4 & 実用的面面 (II) & $\begin{array}{l}\text { 肪害のため画面は損われるが，少しもも } \\
\text { 見しくな画面 }\end{array}$ & $\begin{array}{l}\text { Impairment to picture, but not } \\
\text { objectionable }\end{array}$ \\
\hline 5 & 不良面 面 (I) & 幾分見苦しい画面 & Somewhat objectionable \\
\hline 6 & 不良面 面 (II) & 完全に見芒しい画面 & Definitely objectionable \\
\hline 7 & 㴍めて不良な画面 & 全く使いものにならない画面 & Not usable \\
\hline
\end{tabular}




\section{第 5 表}

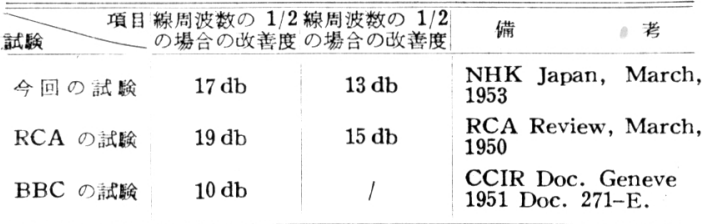

るときは下方に流れるごとく移動し，相当に見苦しい状 態であった。この好害縞の強さはフェージングによって 変化し,ただ最善の場合にのみ(S/I 比 $37 \mathrm{db}$ 程度)殆ん ど目障りにならない程度に弱くなることが認められた。

次に東京および名古屋局の搬送周波数を変化し，両局 の周波数差を $2 \mathrm{kc}, 4 \mathrm{kc}, 6 \mathrm{kc}$ 程度に調整して受信し た結果第 5 図 (b) (c)に示すごとく，周波数差の増大に 伴って妨害縞は順次細かくなり，6 kc の場合は S/I 比最 悪の場合においても, 室内実騒の結果と同栚 10 数 $\mathrm{db} の$ 改善効果のあることが確認された。

上記の結果に基づき昭和 30 年 2 月名古屋局の周波数 を $-10 \mathrm{kc}$ オフットすることが允許され，その落成検 査を兼称て長野県飯田市に抢いて受信試験が行われた。 同地における東京局および名古屋局の電界強度はそれぞ れ $20 \sim 40 \mathrm{db}$ 扎よび $40 \sim 60 \mathrm{db}$ 程度で, 静岡市におけ ると同様相当な混信妨害が認められたが，名古屋局を 10 kc オフセットした結果は著しく改善された（第 6 図参 照)。受像地点における両局の電界比は約 $20 \mathrm{db}$ で, フ ェージングは東京局の電波において僅かに $\pm 1 \mathrm{db}$ 程度 認めら机るのみで, 名古屋局の電波については殆んど認
められず非常汇安定で, 名古屋向壮の受信空中線を設備 すれば, S/I 比 $30 \mathrm{db}$ 以上の受像機入力が得られたが,

第 6 図は特に混信の軽減効果を明らかにするため, 受信 空中線の方向を調整乙て受像機入力の $\mathrm{S} / \mathrm{I}$ 比を $20 \mathrm{db}$ と して撮影したものである。

\section{V. 結言}

上述のごとくオフセット・キャリヤー方式は非常に効 果的ではあるが, 完全なる混信妨害除去法ではないので, 希望局と妨害局の電界比が小さくなるに従い妨害縞が目 立ち, 更に搬送波と側帯波間の混変調成分等のため画面 が荒れ，分解能が少化する。また妨害縞の現われない同 期方式に扮いても希望局と妨害局のプログラムの相違, あるいは位相差のために 2 重像が生ずる（第 7 図参照）。

従って可及的同一周波妨害を生じないよ5な放送局の 配置並びに周波数の割当に努力し，止むを得ざる場合の 救済策としてオフセット方式を利用すると共に, 受信者 側に扮いても受信空中線を適当に設備して混信妨害を除 去することが望まれる。

最後に本試験は郵政省電波監理局はじめ関倸各位の理 解ある御協力によって実施されたことを附記して謝意に 代える。(勧者の横顔は 12 頁に提载) (昭和 30 年 7 月 2 日受付)

[参考交献]

(1) A Study of Co-channel and Adjacent-channel Interference of TV Signals, Part 1 RCA Review, March, 1950

2 CCIR. $\mathrm{V}$ th, Plenary Assembly, Geneve, 1951. Doc., 271-E, 11, June 1951. (United Kingdom)

3) 須田, 林; テレビジョン・オフセットキャリヤー視覚試験結果 NHK 技術研究 No. 15, March, 1954.

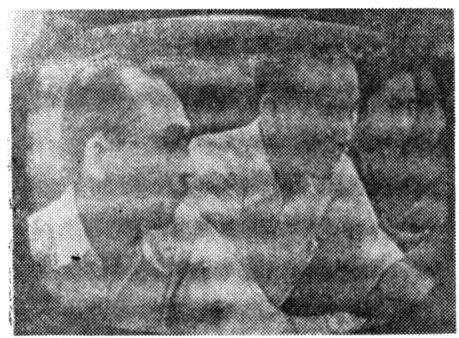

(a) オフセットしない場合

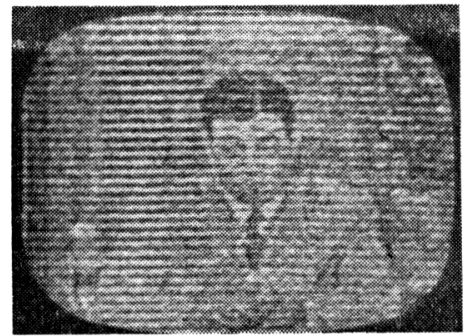

(b) $2 \mathrm{kc}$ オフセットの堨合

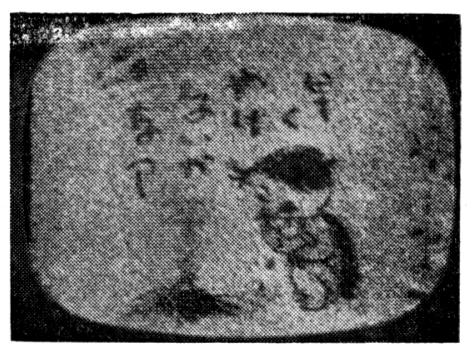

(c) $6 \mathrm{kc}$ オフセットの場合

第 5 図静岡県民会館屋上に打汓る受像写真

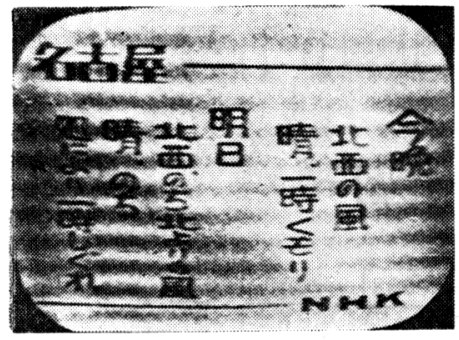

(a) オフセットしない場合

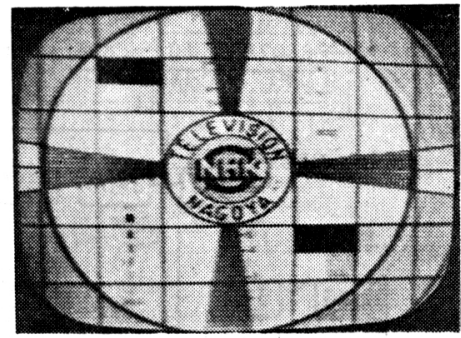

(b) $10 \mathrm{kc}$ オフセットの場合

第6 図飯田市に学忛る受像写真

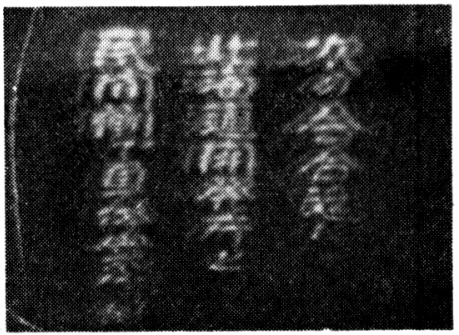

第 7 図完全同期の場合の 2 重 像妨害 